\title{
Peranan Subsektor Kehutanan dalam Pembangunan Wilayah Provinsi Jawa Barat: Pendekatan Input-Output dan Pewilayahan
}

\author{
The Role of the Forestry Subsector in the Regional Development \\ of West Java Province: Input-Output and Clustering Approach
}

\author{
Desli Triman Zendrato ${ }^{1 *}$, Ernan Rustiadi ${ }^{2}$ \& Omo Rusdiana ${ }^{2}$ \\ ${ }^{1}$ Program Studi Ilmu Perencanaan Wilayah, Sekolah Pascasarjana Institut Pertanian Bogor, \\ Jalan Meranti Kampus IPB Dramaga Bogor 16680, Indonesia; ${ }^{2}$ Pusat Pengkajian Perencanaan dan \\ Pengembangan Wilayah (P4W) LPPM, Institut Pertanian Bogor, Kampus IPB Baranangsiang, Jalan Raya \\ Pajajaran, Bogor 16127 Indonesia; ${ }^{*}$ Penulis Korespondensi: e-mail: detriz86@gmail.com
}

(Diterima: 7 Oktober 2019; Disetujui: 28 Januari 2020)

\begin{abstract}
West Java Province has a problem to balance economic growth, population welfare, and environmental sustainability. Land requirements to support economic activities have caused land conversion and land use misalignment that are not in line with their function and carrying capacity. This research is aimed to analyze the role of the forestry subsector within the regional economy, how the alignments between forest area use and spatial planning, and to analyze regional typology based on environment carrying capacity based on ecosystem services. Research methods used in this research include Input-Output Analysis, Spatial Analysis, Principal Component Analysis (PCA), and Spatial Clustering Analysis. Results of the alignment analysis between land use/land cover and spatial planning showed that about $20.8 \%$ or 167,473 ha of forest area experienced land use/land cover changes. Results of the Input-Output analysis showed that the role of the forestry subsector in using outputs from other sectors and providing outputs for other sectors were low. West Java Province can be divided into 4 clusters: center of paddy production, regions that are dominated by forest, densely populated regions, and drought-prone regions.
\end{abstract}

Keywords: forestry, input-output, spatial clustering, spatial planning

\begin{abstract}
ABSTRAK
Provinsi Jawa Barat memiliki permasalahan besar untuk menyeimbangkan pertumbuhan ekonomi, kesejahteraan penduduk, dan keberlanjutan lingkungan. Kebutuhan lahan untuk mendukung kegiatan perekonomian menyebabkan terjadinya konversi lahan serta ketidakselarasan penggunaan lahan yang tidak sesuai fungsi dan daya dukungnya. Penelitian ini bertujuan untuk menganalisis peranan subsektor kehutanan dalam perekonomian wilayah, menganalisis keselarasan penggunaan kawasan hutan terhadap rencana pola ruang, dan menganalisis tipologi wilayah berdasarkan daya dukung lingkungan berbasis jasa ekosistem. Metode yang digunakan dalam penelitian ini yaitu Analisis Input-Output, Spatial Analysis, Principal Component Analysis (PCA), dan Spatial Clustering Analysis. Hasil analisis keselarasan penutupan/penggunaan lahan dan pola ruang menunjukkan sekitar $20.8 \%$ atau 167,473 ha kawasan hutan mengalami perubahan penutupan/penggunaan lahan. Hasil analisis Input-Output menunjukkan peran subsektor kehutanan dalam menyerap output dari sektor lain dan menyediakan output bagi sektor lain rendah.
\end{abstract}


Provinsi Jawa Barat dapat dikelompokkan ke dalam empat cluster, yaitu: kawasan sentra padi, wilayah yang didominasi kawasan hutan, wilayah padat penduduk, dan wilayah rawan kekeringan.

Kata kunci: input-output, kehutanan, pola ruang, spatial clustering

\section{PENDAHULUAN}

Jawa Barat sebagai provinsi dengan jumlah penduduk terbesar yaitu 47.9 juta jiwa menghadapi tantangan untuk menyeimbangkan pertumbuhan ekonomi, kesejahteraan penduduk, dan kelestarian lingkungan. Meningkatnya jumlah penduduk berdampak pada meningkatnya kebutuhan ruang dan akses terhadap sumber daya untuk memenuhi kebutuhan hidup yang pada akhirnya mengarah pada konversi lahan di luar peruntukan dan daya dukungnya.

Salah satu sektor yang terdampak kemajuan pembangunan yaitu sektor kehutanan. Hubungan negatif antara kemajuan pembangunan dan kinerja sektor kehutanan terlihat dari kontribusi sektor kehutanan dalam Produk Domestik Regional Bruto (PDRB). Meskipun PDRB Provinsi Jawa Barat mengalami peningkatan, namun kontribusi subsektor kehutanan terus mengalami penurunan.

Dalam kurun waktu 1999 hingga 2017, kontribusi sektor kehutanan memiliki trend yang terus menurun. Kontribusi sektor kehutanan terhadap PDRB Jawa Barat tahun 1999 sebesar $1.26 \%$, turun menjadi $0.7 \%$ pada tahun 2011, dan turun menjadi $0.082 \%$ pada tahun 2015. Kontribusi subsektor kehutanan pada tahun 2017 hanya sebesar $0.074 \%$ atau Rp1,320.67 juta dari total Produk Domestik Regional Bruto (PDRB) Provinsi Jawa Barat.

Rendahnya kontribusi subsektor kehutanan dapat dilihat dari luas kawasan hutan yang terus berkurang. Tingginya ketergantungan masyarakat terhadap hutan, berdampak pada berkurangnya luas kawasan hutan (deforestasi). Selain itu, rendahnya kontribusi subsektor kehutanan juga diakibatkan pengambilan sumber daya alam (SDA) untuk memenuhi bahan mentah, dan disebabkan adanya penggunaan lahan yang kurang tepat (Putra, 2013; Robhati \& Kusumawardani, 2016).

Pengambilan sumber daya alam secara berlebihan akan menimbulkan biaya recovery yang lebih besar daripada manfaat yang diperoleh dari mengejar pertumbuhan ekonomi (Suryanto, 2009). Menurut Hersaputri \& Santoso (2017), deplesi atau pengurasan sumber daya alam, walaupun dapat diimbangi dengan usaha konservasi namun dampaknya terhadap lingkungan hidup masih akan membekas dan membutuhkan waktu lama untuk pemulihannya.

Untuk mengetahui seberapa besar peranan subsektor kehutanan secara aktual dan potensi kawasan hutan berdasarkan daya dukungnya, diperlukan kajian yang komprehensif. Dalam penelitian ini digunakan pendekatan daya dukung lingkungan berbasis jasa ekosistem. Informasi mengenai jasa ekosistem dibutuhkan dalam perencanaan pembangunan untuk memastikan kelestarian ekosistem yang menghasilkan berbagai jasa ekosistem yang dibutuhkan bagi kehidupan manusia (Riqqi et al., 2018).

Berdasarkan uraian tersebut, ditetapkan tujuan penelitian sebagai berikut: (1) Menganalisis perananan subsektor kehutanan di dalam perekonomian wilayah Provinsi Jawa Barat; (2) Menganalisis keselarasan penggunaan kawasan hutan terhadap rencana pola ruang Provinsi Jawa Barat; dan (3) Menganalisis tipologi wilayah berdasarkan daya dukung lingkungan berbasis jasa ekosistem.

\section{METODOLOGI}

Lokasi penelitian dilaksanakan di Provinsi Jawa Barat terletak di antara $5^{\circ} 50^{\prime}-$ $7^{\circ} 50^{\prime}$ Lintang Selatan dan $104^{\circ} 48^{\prime}-108^{\circ} 48^{\prime}$ Bujur Timur. Objek penelitian meliputi 627 kecamatan di Provinsi Jawa Barat. 
Jenis data yang digunakan dalam penelitian ini adalah data sekunder. Data yang digunakan terdiri dari:

1. Data PODES (Potensi Desa) tahun 2018 yang diperoleh dari BPS;

2. Tabel Input-Output (I-O) Provinsi Jawa Barat Tahun 2015 (52 sektor) dan Peta Rencana Tata Ruang dan Wilayah (RTRW) Provinsi Jawa Barat tahun 20092029 yang diperoleh dari Bappeda Provinsi Jawa Barat;

3. Peta Kawasan Hutan, Peta Penutupan/ Penggunaan Lahan tahun 2017, dan Peta Daya Dukung Daya Tampung Lingkungan Hidup (DDTLH) Berbasis Jasa Ekosistem yang diperoleh dari Kementerian LHK.

\section{Analisis Data \\ 1. Analisis Input-Output (I-O)}

Analisis Input-Output (I-O) bertujuan untuk mengkaji peranan dan keterkaitan sektor kehutanan dengan sektor lainnya dalam perekonomian Provinsi Jawa Barat. Analisis IO didasarkan pada tabel input-output, dimana dalam tabel input-output digambarkan transaksi arus barang dan jasa berupa sistem perhitungan neraca yang mencerminkan hubungan antara sumber input dan penggunaannya antar sektor perekonomian (Yanti, 2015; Chen et al., 2015). Tabel I-O juga digunakan sebagai alat peramal mengenai perubahan kondisi ekonomi atau kebijakan ekonomi (Fatmawati \& Iskandar, 2018). Tahapan analisis dilakukan dengan memperbaharui (updating) Tabel I-O Provinsi Jawa Barat tahun 2015 (52 sektor) sesuai kondisi perekonomian tahun 2017 dengan menggunakan metode RAS.

Metode RAS digunakan untuk menghasilkan matriks teknologi di tahun 1 , yang dinotasikan dengan A(1), berdasarkan suatu matriks teknologi pada tahun 0 , yang dinotasikan dengan $\mathrm{A}(0)$, tanpa harus memiliki $\mathrm{n} 2+\mathrm{n}$ informasi (total permintaan antara, jumlah input antara, dan total output) (Nazara, 2005; Yanti, 2015). Proses iterasi menggunakan metode RAS dihentikan jika penyesuaian baris atau kolom memiliki error $\leq 0.0005$.
Tabel I-O hasil updating selanjutnya digunakan untuk melihat derajat keterkaitan ke depan (forward linkages) dan keterkaitan ke belakang (backward linkages) suatu sektor dalam sistem perekonomian menggunakan persamaan sebagai berikut:

a. Keterkaitan Langsung ke Belakang (Direct Backward Linkage), yang menunjukkan efek permintaan suatu sektor terhadap perubahan tingkat produksi sektor-sektor yang menyediakan input antara bagi sektor tersebut secara langsung, yang dirumuskan ke dalam persamaan (1), sebagai berikut:

$B_{j}=\sum_{i=1}^{n} a_{i j}$

dimana, $a_{i j}=$ unsur matriks koefisien teknologi, dan $n=$ jumlah sektor. Untuk mengukur keterkaitan langsung ke belakang spesifik subsektor kehutanan digunakan persamaan (2), sebagai berikut:

$B_{s_{j}}^{*}=\frac{n a_{i j}}{\Sigma_{j} B_{j}}$

b. Keterkaitan Langsung ke Depan (Direct Forward Linkage), yang menunjukkan banyaknya output suatu sektor yang dipakai oleh sektor-sektor lain. Keterkaitan tersebut dinyatakan dalam persamaan (3), sebagai berikut:

$F_{i}=\sum_{j=1}^{n} a_{i j}$

dimana, $a_{i j}=$ unsur matriks koefisien teknologi, dan $n=$ jumlah sektor. Untuk mengukur keterkaitan langsung ke depan spesifik subsektor kehutanan digunakan persamaan (4), sebagai berikut:

$F_{i s}^{*}=\frac{n \cdot a_{i j}}{\Sigma_{i} F_{i}}$

2. Analisis Spasial

Analisis spasial bertujuan untuk mengkaji keselarasan penutupan/penggunaan lahan aktual (existing) dengan rencana pola ruang, khususnya yang dialokasikan sebagai kawasan hutan. Tahapan analisis dilakukan dengan menumpang-susunkan (overlay) peta Penutupan/Penggunaan Lahan dengan Peta Rencana Pola Ruang, dan Peta Penunjukkan Kawasan Hutan. Hasil overlay selanjutnya diklasifikasikan ke dalam 3 kelas keselarasan, yaitu: 
a. Selaras (S), yaitu penutupan/penggunaan lahan aktual selaras dengan rencana pola ruang

b. Transisi (Tr), yaitu penutupan/penggunaan lahan berbeda dengan rencana pola ruang, namun ada kemungkinan menjadi selaras atau tidak selaras; dan

c. Tidak Selaras (TS), yaitu penutupan/ penggunaan lahan berbeda dengan rencana pola ruang dan sulit atau tidak dapat diubah menjadi selaras.

Hasil klasifikasi keselarasan penggunaan lahan dalam kawasan hutan selanjutnya di-overlay dengan Peta Daya Dukung Lingkungan Berbasis Jasa Ekosistem yang memiliki atribut Indeks Jasa Ekosistem (IJE) dari 9 jenis jasa ekosistem dari fungsi penyedia dan pengaturan, yaitu:

a. Fungsi penyedia = jasa ekosistem penyedia pangan, air bersih dan kayu bakar; dan

b. Fungsi pengaturan = jasa eksosistem pengaturan iklim, tata aliran air, perlindungan banjir, pencegah longsor, pemurni air, dan pengatur kualitas udara.

Dalam penelitian ini nilai IJE dikompositkan sesuai fungsinya, sehingga menghasilkan Indeks Komposit Jasa Ekosistem (IKJE) dari fungsi penyedia dan pengaturan. Hasil komposit IJE selanjutnya disebut sebagai IKJE Penyedia dan IKJE Pengaturan. Untuk menghitung IKJE digunakan persamaan (5) sebagai berikut:

$$
I K J E=\frac{I J E_{i, x}+I J E_{j, x}+I J E_{k, x}+I J E_{i, x}+I J E_{m, x}}{\sum_{i=1}^{\mathrm{n}} I J E}
$$

dimana: $I K J E=$ indeks komposit jasa ekosistem kelompok jasa ekosistem (penyedia, pengaturan, budaya, pendukung); $I J E_{i, x}=$ indeks jasa ekosistem jenis ke- $i$ (misal: pangan, air bersih, serat, bahan bakar, sumber daya genetik) di wilayah ke$x ; \quad \sum_{i=1}^{n} I J E=$ banyaknya jenis jasa ekosistem (misal: kelompok jasa penyedia sebanyak 4 indeks jasa ekosistem).

\section{Analisis Spatial Clustering K-means}

Analisis spatial clustering merupakan salah satu metode pengelompokan spasial dengan menggunakan variabel geografis atau koordinat dari wilayah yang diklasterkan (Rustiadi \& Kobayashi, 2000). Prosedur penelitian ini mengacu pada penelitian yang dilakukan Wulandari (2019), yang menggunakan metode tidak berhierarki menggunakan algoritma k-means. Metode tidak berhierarki dikenal juga sebagai dikenal sebagai metode partitional clustering (Neethu \& Surendran, 2012).

Algoritma $k$-means sangat sederhana untuk diterapkan dan dijalankan, relatif cepat, mudah diadaptasi, dan umum dipraktikan (Tajunisha \& Saravanan, 2011). Metode tidak berhierarki $k$-means selain digunakan untuk analisis data yang relatif besar, juga dapat digunakan untuk menguji konsistensi analisis gerombol dengan metode berhierarki (Latuconsina et al., 2017). Tujuan pengelompokan adalah untuk meminimalkan objective function yang diatur dalam proses clustering, yang pada dasarnya berusaha untuk meminimalkan variasi dalam satu cluster dan memaksimalkan variasi antar cluster (Ediyanto et al., 2013).

Tahapan analisis dilakukan dengan metode Principal Component Analysis (PCA), sehingga diperoleh variabel baru yang saling bebas untuk mempermudah dalam menginterpretasikannya. PCA bekerja dengan mengurangi dimensi sekumpulan data yang terdiri dari variabel yang saling terkait dalam jumlah besar, namun tetap mempertahankan sebanyak mungkin variasi yang ada di dalam data (Mishra et al., 2017).

Variabel baru hasil PCA selanjutnya digunakan sebagai variabel dalam analisis spatial clustering. Hasil analisis akan mengelompokan wilayah-wilayah yang memiliki kedekatan spasial (spatial contiguity) menggunakan pendekatan euclidean distance. Pendekatan euclidean distance sangat baik digunakan dalam pengelompokkan menggunakan algoritma k-means dan untuk menentukan jarak terdekat antara masingmasing objek data dan pusat (Nishom, 2019). Dalam analisis ini, vektor koordinat $X$ dan $Y$ dihitung menggunakan bobot spasial $(\beta)$ sebesar 
$0.5,1$, 2, dan 4 menggunakan persamaan (6), sebagai berikut:

$$
D_{i j}=\sqrt{\begin{array}{c}
\left(Z_{1 i}^{\prime}-Z_{1 j}^{\prime}\right)^{2}+\left(Z_{2 i}^{\prime}-Z^{\prime}{ }_{2 j}\right)^{2}+ \\
\ldots+\left(Z^{\prime}{ }_{m i}-Z^{\prime}{ }_{m j}\right)^{2}+ \\
\beta\left\{\left(X_{i}^{\prime}-X_{j}^{\prime}\right)^{2}+\left(Y_{i}^{\prime}-Y_{j}^{\prime}\right)^{2}\right\}
\end{array}}
$$

dimana, $D_{i j}=$ jarak euclidean berbobot spasial antara $i$ dan $j ; Z_{m i}=$ nilai atribut $i$ untuk variabel z yang terstandardisasi; $Z_{m j}=$ nilai atribut $j$ untuk variabel $Z$ yang terstandardisasi; $X_{i}=$ nilai koordinat lokasi pada sumbu $X ; Y=$ nilai koordinat lokasi pada sumbu $Y ; \beta=$ bobot spasial $(0.5,1,2$, dan 4); dan $m=$ jumlah variabel.

Langkah selanjutnya yaitu menghitung nilai Coeffecient of Variation (CV). Nilai CV sering digunakan untuk mengukur sebaran data statistik yang didasarkan pada nilai rata-rata (mean) dan standar deviasi (Doulah, 2018). Nilai CV dihitung menggunakan persamaan (7) (Rustiadi \& Kobayashi, 2000), sebagai berikut:

$$
C V=\left(\frac{\sigma^{2}}{\bar{x}}\right)
$$

dimana, $\sigma^{2}=$ standard deviasi dari euclidean distance $\left(D_{i j}\right)$; dan $\bar{X}=$ rata-rata euclidean distance $\left(D_{i j}\right)$.

\section{HASIL DAN PEMBAHASAN}

\section{Keterkaitan Subsektor Kehutanan dalam Perekonomian Wilayah}

Analisis keterkaitan bertujuan untuk menggambarkan keterkaitan antara 52 sektor perekonomian di Provinsi Jawa Barat berdasarkan Tabel Input-Output (I-O) hasil updating tahun 2017. Dalam klasifikasi tabel IO Provinsi Jawa Barat, sektor kehutanan diklasifikasikan sebagai Subsektor Kehutanan dan Penebangan Kayu (6). Ada beberapa bentuk keterkaitan yang dapat dilihat menggunakan tabel I-O, diantaranya Direct Backward Linkage $\left(B_{j}\right)$ dan Direct Forward Linkage $\left(F_{i}\right)$. Sektor-sektor dengan nilai $B_{j}$ dan $F_{i}$ tertinggi dan terendah selengkapnya disajikan pada Gambar 1.

Sektor ketenagalistrikan dan industri pengolahan memiliki keterkaitan ke belakang
$\left(B_{j}\right)$ dan ke depan $\left(F_{i}\right)$ yang tinggi, sedangkan sektor hulu yang berbasis sumber daya seperti pertanian, kehutanan, dan perikanan memiliki keterkaitan ke belakang dan ke depan yang rendah. Penelitian yang dilakukan Haris et al. (2017) menunjukkan hal yang sama, dimana sektor industri menjadi leading sektor karena dapat menarik sektor hulu dan mendorong sektor hilirnya sangat baik dan kontribusi sektor industri pada seluruh perekonomian merupakan yang terbesar. Menurut Monika (2014), sektor dengan backward linkage yang lebih tinggi dibanding sektor lainnya berarti ekspansi produksinya lebih bermanfaat bagi perekenomian dalam hal memberikan pengaruh aktivitas produksi, dan sektor dengan forward linkage yang lebih tinggi berarti produksinya relatif lebih sensitif terhadap perubahan output sektor lainnya.

Sektor dengan keterkaitan ke belakang tertinggi yaitu sektor Ketenagalistrikan (27) dengan nilai $B_{j}=1.058$. Nilai tersebut menunjukkan apabila terjadi peningkatan permintaan akhir sektor ketenagalistrikan sebesar Rp1 miliar, maka output sektor lain akan meningkatkan sebesar Rp1.058 miliar. Sektor Ketenagalistrikan memiliki nilai $F i=$ 0.795, yang berarti apabila permintaan seluruh sektor meningkat sebesar Rp1 miliar, maka akan menyebabkan output sektor Ketenagalistrikan (27) meningkat sebesar Rp0.795 miliar.

Sektor yang memiliki nilai $F i$ tertinggi yaitu sektor Perdagangan Besar dan Eceran (32) yaitu 1,491. Hal ini menunjukkan sektor yang paling terdampak apabila permintaan akhir seluruh sektor meningkat sebesar Rp 1 miliar, maka sektor Perdagangan Besar dan Eceran akan menghasilkan output sebesar Rp1,491 miliar.

Peran subsektor Kehutanan dan Penebangan Kayu (6) dalam perekonomian wilayah Provinsi Jawa Barat sangat rendah. Subsektor Kehutanan dan Penebangan Kayu (6) memiliki nilai $B j$ sebesar 0.04, sedangkan nilai Fi-nya sebesar 0.08. Nilai tersebut menunjukkan bahwa, jika terjadi peningkatan 
permintaan akhir subsektor kehutanan sebesar Rp1 miliar, maka output sektor lain akan meningkat secara total sebesar Rp0.04 miliar. Sementara itu, jika setiap kenaikan permintaan akhir seluruh sektor sebesar Rp1 miliar, maka output subsektor kehutanan akan meningkat sebesar Rp0.08 miliar.

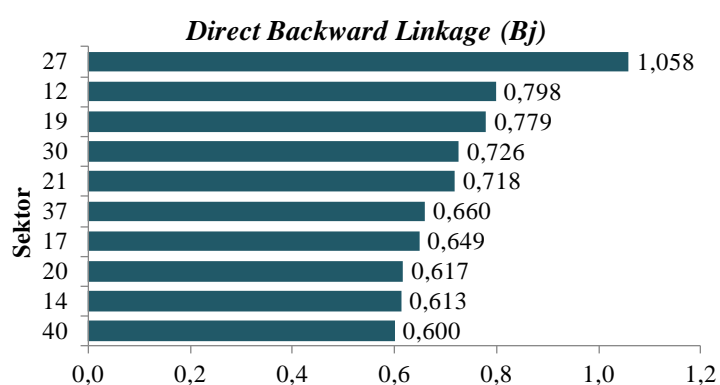

(a)

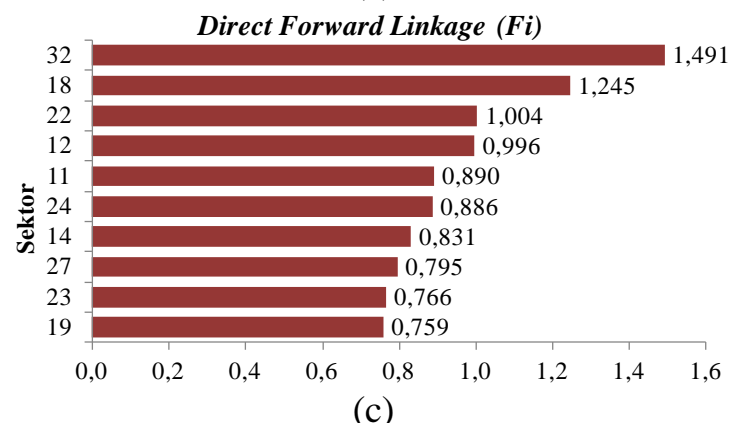

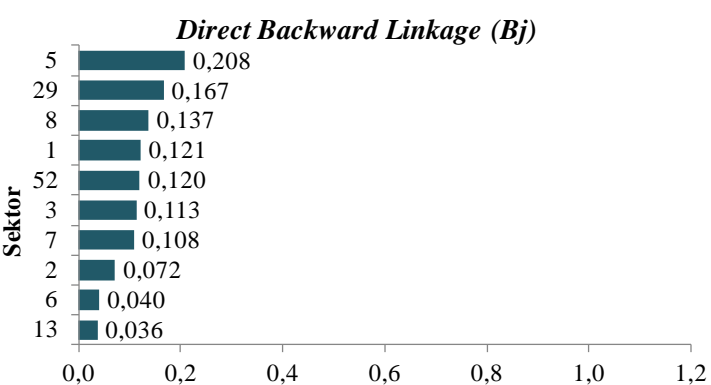

(b)

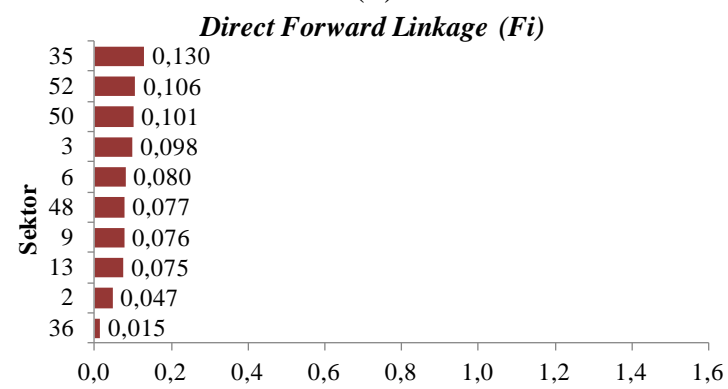

(d)

Keterangan: (1) Tanaman Pangan; (2) Tanaman Hortikultura; (3) Perkebunan; (5) Jasa Pertanian, dan Perburuan; (5) Jasa Pertanian, dan Perburuan; (6) Kehutanan dan Penebangan Kayu; (7) Perikanan; (8) Pertambangan Minyak, Gas dan Panas Bumi; (9) Pertambangan Bijih Logam; (11) Industri Batubara dan Pengilangan Migas; (12) Industri Makanan dan Minuman; (13) Pengolahan Tembakau; (14) Industri Tekstil dan Pakaian Jadi; (17) Industri Kertas dan Barang dari Kertas, Percetakan dan Reproduksi Media Rekaman; (18) Industri Kimia, Farmasi dan Obat Tradisional; (19) Industri Karet, Barang dari Karet dan Plastik; (20) Industri Barang Galian bukan Logam; (21) Industri Logam Dasar; (22) Industri Barang dari Logam, Komputer, Barang Elektronik, Optik dan Peralatan Listrik; (23) Industri Mesin dan Perlengkapan YTDL; (24) Industri Alat Angkutan; (27) Ketenagalistrikan; (29) Pengadaan Air, Pengelolaan Sampah, Limbah dan Daur Ulang; (30) Konstruksi; (32) Perdagangan Besar dan Eceran, Bukan Mobil dan Sepeda Motor; (35) Angkutan Laut; (36) Angkutan Sungai Danau dan Penyeberangan; (37) Angkutan Udara; (40) Penyediaan Makan Minum; (48) Administrasi Pemerintahan, Pertahanan dan Jaminan Sosial Wajib; (50) Jasa Kesehatan dan Kegiatan Sosial; dan (52) Lainnya.

Gambar 1. Sepuluh sektor dengan nilai $B_{j}$ tertinggi (a), Bj terendah (b), $F i$ tertinggi (c) dan Fi terendah (d).

Jika dilihat secara spesifik, subsektor Kehutanan dan Penebangan Kayu (6) memiliki Keterkaitan Langsung ke Belakang Spesifik $\left(B . j^{*}\right)$ dengan 38 sektor. Sektor dengan nilai $B . j^{*}$ tertinggi yaitu sektor Tanaman Pangan (1) dengan nilai 0.398 yang berarti setiap menghasilkan output sebesar Rp1 miliar, sektor Kehutanan dan Penebangan Kayu (6) membutuhkan input antara dari sektor Tanaman Pangan (1) sebesar Rp0.398 miliar. Sepuluh sektor dengan $B . j^{*}$ tertinggi disajikan pada Gambar 2a.

Subsektor Kehutanan dan Penebangan Kayu (6) memiliki Keterkaitan Langsung ke Depan Spesifik (Fi.*) dengan 34 sektor. Sektor
Industri Kayu, Barang dari Kayu dan Gabus dan Barang Anyaman dari Bambu, Rotan dan Sejenisnya (16) merupakan sektor dengan nilai Fi.* tertinggi yaitu 0.368 . Hal ini berarti setiap kenaikan permintaan akhir subsektor Kehutanan sebesar Rp1 miliar akan digunakan sebagai input antara bagi sektor Industri Kayu, Barang dari Kayu dan Gabus dan Barang Anyaman dari Bambu, Rotan dan Sejenisnya (16) sebesar Rp0.368 miliar. Sektor lain yang juga memiliki nilai $\mathrm{Fi}^{*}$ yang tinggi yaitu sektor Industri Furnitur (25) dan Industri Kertas dari barang dari Kertas, Percetakan dan Reproduksi Media Rekaman (17). Nilai Fi.* yang tinggi dari ketiga sektor tersebut 
disebabkan kebutuhan bahan baku dari subsektor Kehutanan dan Penebangan Kayu (6) dalam menghasilkan output-nya oleh sektor tersebut. Sepuluh sektor dengan nilai $\mathrm{Fi}^{*}$ tertinggi disajikan pada Gambar 2b.

Nilai $\mathrm{Bj}, \mathrm{Fi}, \mathrm{B.j}{ }^{*}$ dan $\mathrm{Fi}$.* subsektor Kehutanan dan Penebangan Kayu (6) yang rendah menunjukkan bahwa sektor ini bukan sektor basis di Jawa Barat. Namun dalam penelitian yang dilakukan oleh Widianingsih et al. (2015), berdasarkan data perekonomian

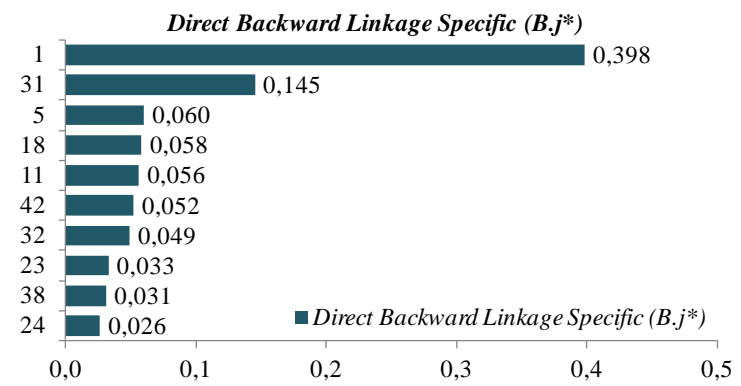

(a) tahun 2003-2012 menunjukkan potensi subsektor Kehutanan berpotensi menjadi sektor basis di masa depan jika dibandingkan subsektor pertanian lainnya. Subsektor Kehutanan termasuk dalam kategori subsektor berkembang, sedangkan subsektor pertanian lainnya termasuk dalam kategori maju tapi tertekan (subsektor tanaman bahan makanan dan hortikultura dan subsektor perternakan) dan kategori tertinggal (subsektor perkebunan dan subsektor perikanan).

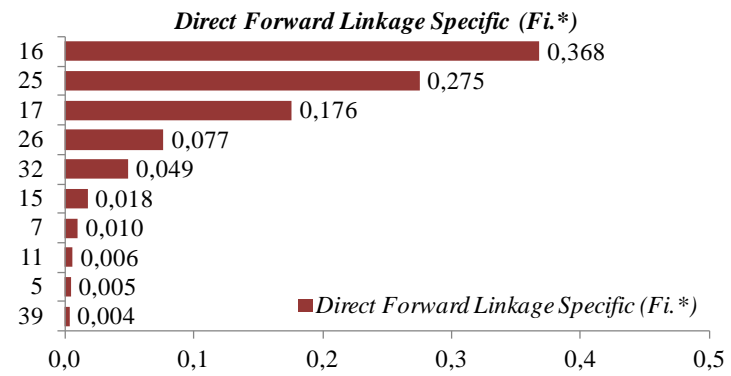

(b)

Keterangan: (1) Tanaman Pangan; (5) Jasa Pertanian, dan Perburuan; (7) Perikanan; (11) Industri Batubara dan Pengilangan Migas; (15) Industri Kulit, Barang dari Kulit dan Alas Kaki; (16) Industri Kayu, Barang dari Kayu dan Gabus dan Barang Anyaman dari Bambu, Rotan dan Sejenisnya; (17) Industri Kertas dan Barang dari Kertas, Percetakan dan Reproduksi Media Rekaman; (18) Industri Kimia, Farmasi dan Obat Tradisional; (23) Industri Mesin dan Perlengkapan; (24) Industri Alat Angkutan; (25) Industri Furnitur; (26) Industri pengolahan lainnya, jasa reparasi dan pemasangan mesin dan peralatan; (31) Perdagangan Mobil, Sepeda Motor dan Reparasinya; (32) Perdagangan Besar dan Eceran, Bukan Mobil dan Sepeda Motor; (38) Pergudangan dan Jasa Penunjang Angkutan, Pos dan Kurir; (39) Penyediaan Akomodasi; dan (42) Jasa Perantara Keuangan.

Gambar 2. (a) Sepuluh sektor dengan keterkaitan langsung ke belakang spesifik tertiinggi; dan (b) Sepuluh sektor dengan keterkaitan langsung ke depan spesifik tertinggi

\section{Keselarasan Penggunaan Lahan pada Kawasan Hutan}

Hasil analisis keselasaran penggunaan lahan pada kawasan hutan menunjukkan dari 3.7 juta hektar wilayah Provinsi Jawa Barat, kurang lebih 8.2\% atau 305,176.8 hektar tidak selaras dengan rencana pola ruang. Kurang lebih 54.9\% dari penggunaan lahan yang tidak selaras merupakan kawasan hutan. Ketidakselarasan penggunaan lahan pada kawasan hutan meliputi area seluas 167,473 hektar atau 20.8\%.

Ketidakselarasan terbesar ditemukan pada kawasan Hutan Lindung (HL) seluas 68.2 ribu hektar, di Hutan Produksi (HP) 49.5 ribu hektar, di Hutan Produksi Terbatas 27.3 ribu hektar dan di Kawasan Suaka/Pelestarian Alam seluas 22.5 ribu hektar. Sebaran kelas keselarasan penggunaan kawasan hutan selengkapnya disajikan pada Gambar 3.

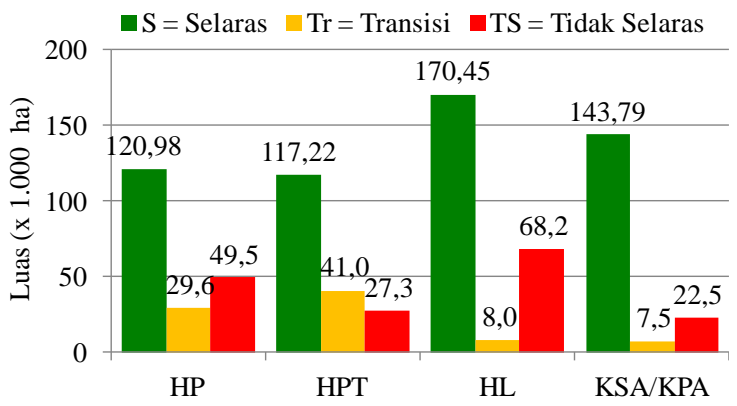

Gambar 3. Klasifikasi keselarasan penggunaan lahan dalam kawasan hutan

Bentuk ketidakselarasan penggunaan lahan di dalam kawasan hutan menjadi kegiatan non-kehutanan antara lain: perkebunan, pertanian campuran, sawah, pemukiman, pertambangan dan tambak. Hasil penelitian yang dilakukan oleh Fajarini et al., (2015) dinamika dan prediksi perubahan di Kabupaten Bogor lahan tahun 2025 menunjukkan bahwa, sekitar 20.6\% kawasan hutan di Kabupaten 
Bogor diprediksi berubah menjadi perkebunan, sawah, tegalan, lahan terbangun, dan lain-lain. Hasil penelitian Roy et al. (2017) terhadap penggunaan lahan di Kabupaten Bogor tahun 2016 menunjukkan bahwa, ketidakselarasan penggunaan lahan dalam kawasan hutan terjadi pada berbagai fungsi hutan (produksi, lindung, dan konservasi) sebagian besar digunakan untuk kegiatan pertanian dan lahan terbangun.

Menurut Fajarini et al. (2015), berkurangnya luas kawasan hutan mengancam fungsi hutan sebagai kawasan lindung dan konservasi dan sebagai daerah resapan air. Sebagai contoh kasus, hasil studi Kusumaningtyas dan Chofyan (2013) menunjukkan berkurangnya kawasan hutan lindung di pesisir utara Kabupaten Subang menjadi perkebunan dan sawah tadah hujan yang mencapai lebih dari 50\% telah menyebabkan berkurangnya persediaan air dan terjadi banjir pada bagian hilir.

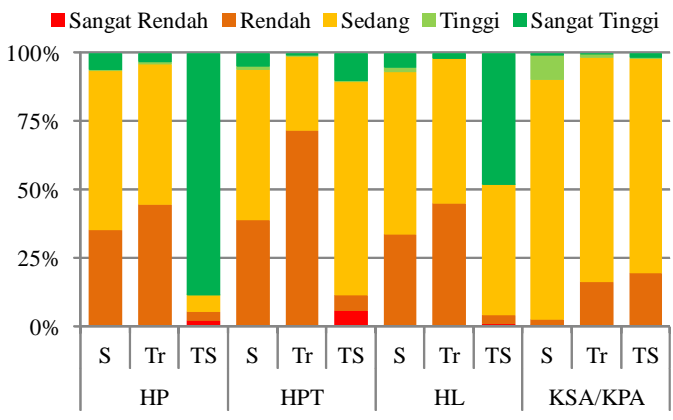

(a)
Dengan mengintegrasikan informasi daya dukung lingkungan berbasis jasa ekosistem, dapat diketahui bagaimana hubungan antara ketidakselasaran penggunaan kawasan hutan terhadap daya dukung lingkungan jasa ekosistem kawasan hutan. semakin baik daya dukung suatu lokasi atau ekoregion, maka ekosistem di ekoregion tersebut memiliki kualit yang baik dan dapat berfungsi denga baik untuk menyediakan jasa ekosistemnya (Riqqi et al., 2018).

Sebaran kelas daya dukung lingkungan berbasis jasa ekosistem pada berbagai fungsi kawasan hutan dan kelas keselarasannya ditampilkan pada Gambar 4. Secara umum, potensi jasa ekosistem penyedia di berbagai fungsi kawasan hutan dan kelas keselarasannya termasuk dalam kelas rendah-sedang [Gambar 4a], sedangkan potensi jasa ekosistem pengaturannya didominasi kelas sedang-tinggi [Gambar 4b].

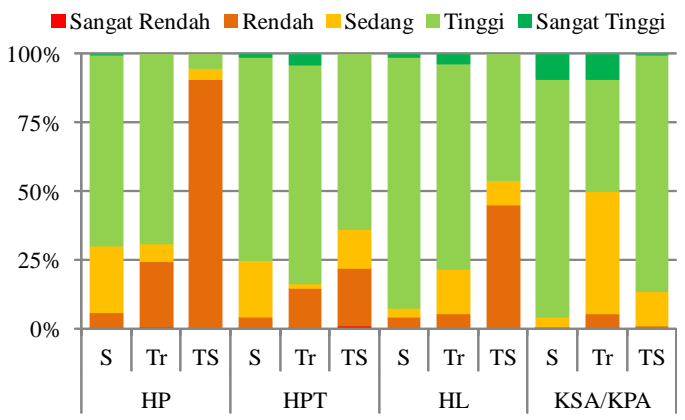

(b)

Gambar 4. Sebaran kelas daya dukung lingkungan berbasis jasa ekosistem pada berbagai status kawasan hutan: (a) jasa ekosistem penyedia; dan (b) jasa ekosistem pengaturan

Kondisi yang berbeda ditemukan pada kawasan hutan yang Tidak Selaras (TS). Lebih dari 75\% Hutan Produksi (HP) dan hampir 50\% Hutan Lindung yang termasuk kelas Tidak Selaras (TS) memiliki potensi jasa penyedia yang sangat tinggi, sedangkan potensi jasa pengaturannya termasuk kategori rendah. Hal ini menunjukkan indikasi telah terjadinya deforestasi atau hilangnya tutupan hutan yang berdampak pada degradasi, yaitu penurunan fungsi akibat tingkat penggunaan yang melampaui kemampuannya (Wahyunto \& Dariah, 2014).

Ekawati dan Nurrochmat (2014) menyatakan bahwa terdapat hubungan negatif antara manfaat ekonomi yang diperoleh masyarakat dari hutan dengan kelestarian hutan. Dalam penelitian Robhati dan Kusumawardani (2016), dijelaskan bahwa kerugian yang ditimbulkan akibat deforestasi lebih besar dari manfaat ekonomi yang diterima.

Meskipun potensi jasa ekosistem penyedia dan pengaturan tersebut bersifat trade off antara jasa penyedia dan jasa pengaturan dari kawasan hutan, namun penggunaan kawasan hutan diluar fungsi dan peruntukkannya akan berdampak pada pemanfaatan sumber daya hutan yang tidak lestari. Dengan pengertian lain, penggunaan 
kawasan hutan untuk keperluan lain (misalnnya: untuk tanaman pangan dan hortikultura) harus memperhatikan kapasitas hutan itu sendiri, agar beragam manfaat hutan tidak hilang.

Penggunaan kawasan hutan untuk kegiatan non kehutanan sebaiknya disertai dengan teknik konservasi tanah dan air yang memadai sebagai upaya memelihara dan mempertahankan fungsi hutan itu sendiri. Sebagai contoh kasus, dalam penelitian yang dilakukan oleh Hidayat et al. (2013) dijelaskan bahwa, perubahan penggunaan lahan hutan yang menjadi lahan pertanian dan pengelolaan pertanian yang belum menerapkan teknik konservasi tanah dan air yang memadai berdampak pada menurunnya fungsi hidrologi DAS Citarum Hulu.

\section{Tipologi Wilayah Berdasarkan Daya Dukung Lingkungan Berbasis Jasa Ekosistem}

Tipologi wilayah berdasarkan Daya Dukung Lingkungan Berbasis Jasa Ekosistem bertujuan untuk menentukan pengelompokkan wilayah sesuai karakteristiknya berdasarkan Daya Dukung Lingkungan Berbasis Jasa Ekosistem. Terdapat tiga kriteria yang digunakan dalam menentukan pengelompokan wilayah, yaitu nilai factor loading, grafik Plot of Means for Each Cluster dan nilai Coeffecient of Variation (CV) yang diperoleh dari hasil Principal Component Analysis (PCA). Metode PCA merupakan analisis statistik multivariat yang sering digunakan untuk meringkas dimensi data, memudahkan eksplorasi data tanpa menghilangkan informasi penting dari data tersebut, dan menghilangkan masalah multikolinearitas (Reza \& Ruhi, 2015; Sudrajat, 2016).

Hasil analisis PCA diperoleh nilai commulative dari variabel baru sebesar $73.41 \%$, yang menandakan variabel baru telah valid (\% commulative $>70 \%$ ). Hasil factor loading [Tabel 1] menunjukkan variabel penting di setiap faktor yang ditunjukkan dengan nilai $>0.7$ (angka yang dicetak tebal). Tanda “_“ (negatif) menunjukkan hubungan antar variabel. Variabel penting masing-masing faktor antara lain: Factor 1 = Luas Sawah, Persentase Sawah, dan Produksi Padi; Factor 2 $=$ Luas Kawasan Hutan, dan Persentase Kawasan Hutan; Factor 3 = Rumah Tangga Pengguna Listrik PLN, Luas Lahan Terbangun, dan Persenase Lahan Terbangun; Factor $4=$ Banyaknya Kejadian Kekeringan Lahan; dan Factor 5 = Produksi Kayu.

Tabel 1. Hasil factor loading analisis PCA

\begin{tabular}{lrrrrr}
\hline Variabel & Factor 1 & \multicolumn{1}{c}{ Factor 2 } & Factor 3 & \multicolumn{1}{c}{ Factor 4 } & Factor 5 \\
\hline Kepadatan Penduduk (jiwa/km²) & -0.489199 & -0.154052 & -0.665674 & -0.257852 & 0.153595 \\
Rumah Tangga Pengguna Listrik PLN & -0.000344 & -0.066738 & $\mathbf{- 0 . 8 5 3 3 6 7}$ & 0.142531 & -0.092335 \\
Luas DDJEP Kelas Rendah-Sangat Rendah & -0.508491 & 0.000074 & -0.690792 & -0.256940 & 0.137845 \\
Luas DDJEA Kelas Rendah-Sangat Rendah & 0.263161 & -0.422427 & -0.586562 & -0.394262 & 0.176946 \\
Luas Lahan Terbangun & 0.044739 & -0.127246 & $\mathbf{- 0 . 8 0 9 6 6 7}$ & -0.021766 & -0.084657 \\
Luas Kawasan Hutan & 0.152756 & $\mathbf{0 . 9 0 1 7 0 9}$ & 0.104775 & 0.127267 & -0.032627 \\
Luas Sawah & $\mathbf{0 . 9 2 1 7 8 0}$ & 0.050696 & 0.065395 & -0.020794 & 0.002037 \\
Persentase Lahan Terbangun & -0.455517 & -0.201163 & $\mathbf{- 0 . 7 5 4 7 6 0}$ & -0.297133 & 0.135351 \\
Persentase Kawasan Hutan & 0.033244 & $\mathbf{0 . 8 7 5 2 9 8}$ & 0.269888 & 0.152727 & -0.022345 \\
Persentase Sawah & $\mathbf{0 . 7 3 8 8 4 4}$ & -0.464521 & 0.191731 & -0.140577 & 0.065515 \\
Produksi Padi & $\mathbf{0 . 7 9 3 5 0 4}$ & 0.181749 & 0.005818 & 0.037030 & 0.010800 \\
Produksi Kayu & -0.008695 & 0.048412 & 0.025001 & -0.032313 & $\mathbf{- 0 . 9 1 5 7 9 2}$ \\
Banyaknya Kejadian Longsor & -0.176869 & 0.406910 & 0.228270 & 0.573913 & -0.120397 \\
Banyaknya Kejadian Banjir/Banjir Bandang & 0.033428 & 0.157931 & -0.125197 & 0.550600 & -0.252979 \\
Banyaknya Kejadian Kebakaran Hutan & -0.018448 & 0.235312 & 0.044669 & 0.625873 & 0.197421 \\
Banyaknya Kejadian Kekeringan Lahan & 0.108270 & -0.127393 & 0.185856 & $\mathbf{0 . 7 1 1 9 9 6}$ & 0.088338 \\
Expl.Var & 2.870825 & 2.358358 & 3.447663 & 1.990351 & 1.077840 \\
Prp.Totl & 0.179427 & 0.147397 & 0.215479 & 0.124397 & 0.067365 \\
\hline
\end{tabular}

Keterangan: DDJEP = Daya dukung lingkungan berbasis jasa ekosistem penyedia; DDJEA = Daya Dukung lingkungan berbasis jasa ekosistem pengaturan; PLN = Perusahaan Listrik Negara 
Hasil factor loading juga menunjukkan variabel Luas Daya Dukung Lingkungan Berbasis Jasa Ekosistem Penyedia (DDJEP) dan Pengaturan (DDJEA) Kelas Rendah-Sangat Rendah tidak menjadi variabel penting yang mempengaruhi pembentukan cluster.

Grafik Plot of Means for Each Cluster yang disajikan pada Gambar 6 menunjukan hubungan antar cluster dan faktor yang paling dominan mempengaruhi pembentukan cluster. Grafik ini tidak bisa dipisahkan dari hasil factor loading, dimana posisi plot setiap faktor akan menentukan interpretasi cluster yang terbentuk.

Nilai Coeffecient of Variation (CV) menunjukkan rasio antara nilai tengah (means) dengan standard deviasi. Semakin kecil nilai $\mathrm{CV}$, semakin kecil perbedaan varians di dalam cluster.

Berdasarkan ketiga kriteria tersebut hasil cluster yang paling baik untuk menentukan tipologi wilayah adalah cluster dengan bobot spasial $(\beta)=2$, seperti ditampilkan pada Gambar 7(b). Cluster dengan bobot spasial 0.5, dan 1 tidak dapat digunakan untuk menentukan tipologi wilayah karena ditemukan banyak pencilan (outlier), sedangkan pada cluster dengan bobot spasial 4 memiliki karakteristik yang tidak jelas dan pengaruh faktor kedekatan spasial lebih dominan.

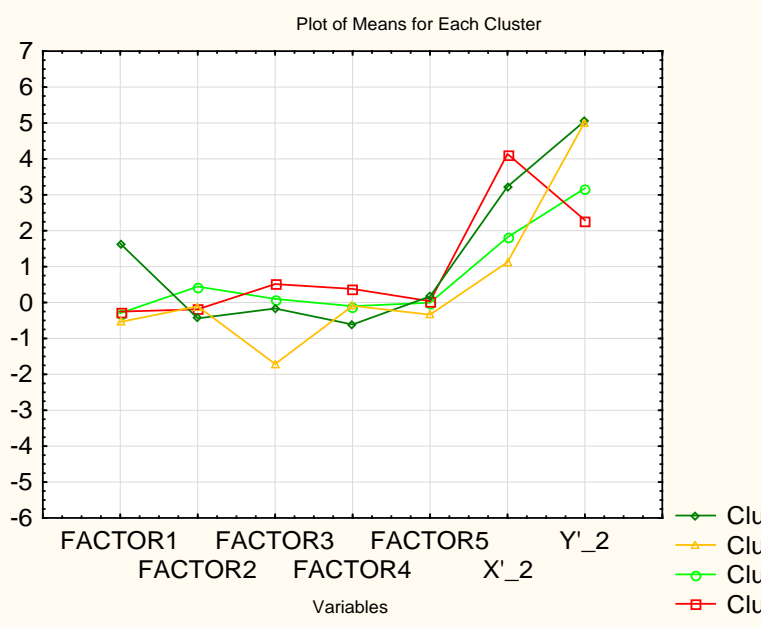

(a)
Tipologi wilayah berdasarkan cluster dengan bobot spasial 2 adalah sebagai berikut: Cluster 1, menggambarkan wilayah sentra penghasil padi, dimana luas lahan sawah dan produksi padi sangat dominan di wilayah tersebut. Cluster 2, menggambarkan daerah dengan luas dan persentase kawasan hutan yang dominan. Cluster 3, menggambarkan ciri wilayah perkotaan yang ditandai rumah tangga pengguna listrik PLN dan luas lahan terbangun (build up area) yang dominan. Cluster 4, menggambarkan wilayah yang sering mengalami kekeringan. Sebaran cluster menurut kecamatan dan kabupaten/kota disajikan pada Gambar 7.

Hasil cluster menunjukkan sebagian besar kabupaten/kota di Jawa Barat memiliki tipologi yang dipengaruhi luas kawasan hutan, namun faktor produksi kayu (Factor 5) belum menjadi faktor penting dalam membentuk cluster. Hal ini mengindikasikan manfaat hasil hutan kayu tidak menjadi manfaat utama dan tidak signifikan mempengaruhi pembentukan cluster. Di sisi lain keberadaan kawasan hutan turut mempengaruhi pembentukan cluster, yang menunjukkan adanya keterkaitan antara manfaat hutan selain kayu yang berpengaruh terhadap pembentukan cluster di sebagian besar kabupaten/kota di Jawa Barat.

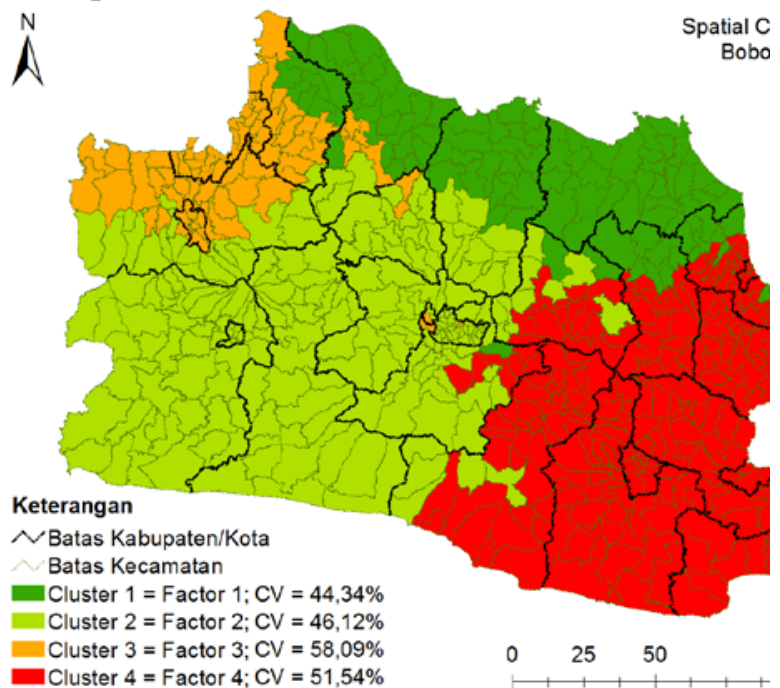

(b)

Gambar 6. (a) Grafik Plot of Means of Each Cluster, dan (b) Peta sebaran cluster dengan bobot spasial 2 


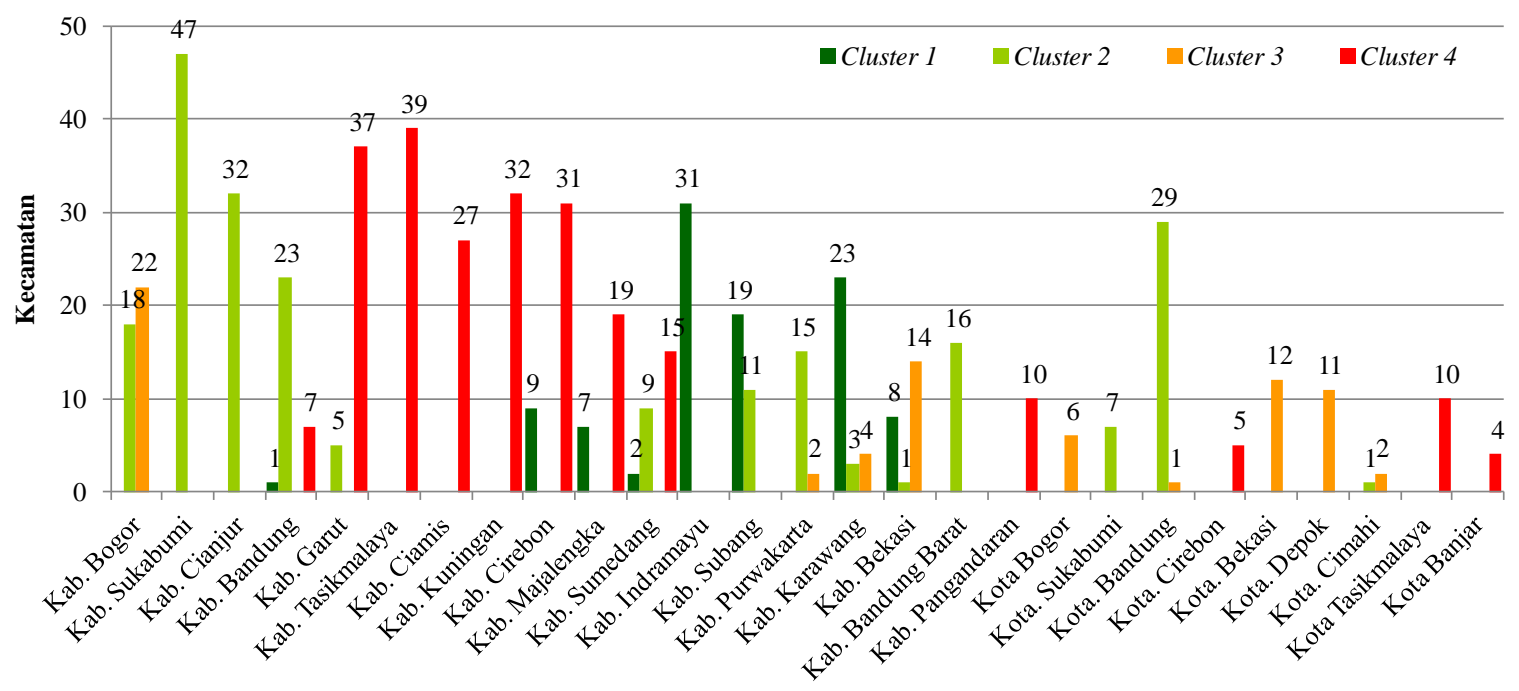

Gambar 7. Sebaran cluster menurut kecamatan dan kabupaten/kota.

\section{KESIMPULAN DAN SARAN}

\section{Kesimpulan}

1. Subsektor Kehutanan memiliki peran yang rendah dalam perekonomian Jawa Barat, namun memiliki kemampuan mendorong sektor hilir lebih baik daripada menarik sektor hulu. Untuk itu diperlukan upaya pengembangan usaha subsektor kehutanan dan sektor terkait lainnya untuk meningkatkan kontribusi subsektor kehutanan dalam perekonomian Provinsi Jawa Barat.

2. Sekitar $8.2 \%$ kawasan hutan di Jawa Barat tidak selaras dengan rencana pola ruang, dimana sebagian besar terjadi pada hutan produksi dan hutan lindung. Potensi jasa ekosistem penyedia (pangan, air bersih, dan kayu bakar) pada hutan produksi dan hutan lindung yang tidak selaras dengan pola ruang didominasi potensi jasa ekosistem penyedia kelas sangat tinggi, sedangkan potensi jasa ekosistem pengaturannya (pengaturan iklim, tata aliran air, perlindungan banjir, pencegah longsor, pemurni air, dan pengatur kualitas udara) cenderung didominasi kelas rendah.

3. Tipologi wilayah Provinsi Jawa Barat Berdasarkan Daya Dukung Lingkungan Berbasis Jasa Ekosistem dapat dikelompokkan ke dalam 4 cluster dengan penciri sebagai berikut: Cluster 1, mencirikan wilayah sentra penghasil padi; Cluster 2 mencirikan wilayah yang didominasi kawasan berhutan; Cluster 3, mencirikan wilayah perkotaan yang padat penduduk; dan Cluster 4, mencirikan wilayah rawan kekeringan.

\section{Saran}

1. Perlu adanya penelitian lanjutan dengan menggunakan variabel hasil valuasi ekonomi beragam jenis ekosistem di dalam analisis Input-Output.

2. Informasi Daya Dukung Lingkungan Berbasis Jasa Ekosistem sangat baik digunakan dalam penyusunan Rencana Tata Ruang dan Wilayah (RTRW).

\section{UCAPAN TERIMA KASIH}

Ucapan terima kasih disampaikan kepada Pusat Pembinaan, Pendidikan dan Pelatihan Perencanaan Badan Perencanaan Pembangunan Nasional (Pusbindiklatren Bappenas) atas bantuan beasiswa dan biaya penelitian. Ucapan terima kasih disampaikan pula kepada Badan Pusat Statistik Provinsi Jawa Barat, Badan Perencanaan Pembangunan Daerah (Bappeda) Provinsi Jawa Barat, Kementerian Lingkungan Hidup dan Kehutanan atas bantuannya dalam pengumpulan data. 


\section{DAFTAR PUSTAKA}

Chen, W., Xu, D., \& Liu, J. (2015). The Forest Resources Input-Output Model: A Application in China. Ecological Indicators, 51 (2015), 87-97.

Doulah, M. S. U. (2018). Alternative Measures of Standard Deviation Coefficient of Variation and Standard Error. International Journal of Statistics and Applications, 8 (6), 309-315.

Ediyanto, Mara, M. N., \& Satyahadewi, N. (2013). Pengklasifikasian Karakteristik dengan Metode K-means Cluster Analysis. Buletin Ilmiah Mat. Stat. dan Terapannya (Bimaster), 2 (2), 133-136.

Ekawati, S. \& Nurrochmat, D. R. (2014). Hubungan Modal Sosial dengan Pemanfaatan dan Kelestarian Hutan Lindung. Jurnal Analisis Kebijakan Kehutanan, 11 (1), 40-53.

Fajarini, R., Barus, B., \& Panuju, D. R. (2015). Dinamika Perubahan Penggunaan Lahan dan Prediksinya untuk Tahun 2025 serta Keterkaitannya dengan Perencanaan Tata Ruang 2005-2025 di Kabupaten Bogor. Jurnal Tanah dan Lingkungan, 17 (1), 815.

Fatmawati A., \& Iskandar, D. D. (2018). Analisis Perubahan Struktur Ekonomi (Economic Landscape) Jawa Tengah (Analisis Input Output Periode tahun 2000-2013. Jurnal Dinamika Ekonomi Pembangunan (JDEP), 1 (3), 46-70.

Haris, W. H., Sarma, M. \& Falatehan, A. F. (2017). Analisis Peranan Subsektor Tanaman Pangan terhadap Perekonomian Jawa Barat. Journal of Regional and Rural Development Planning, 1 (3), 231-242.

Hersaputri, L. D., \& Santoso, E. B. (2017). Estimasi Deplesi Lingkungan Subsektor Kehutanan di Jawa Timur. Jurnal Teknik ITS, 6 (2), 2337-3520.
Hidayat, Y., Murtilaksono, K., Wahjunie, E. D., \& Panuju, D. R. (2013). Pencirian Debit Aliran Sungai Citarum Hulu. Jurnal Ilmu Pertanian Indonesia (JIPI), 18 (2), 109-114.

Kusumaningtyas, R., \& Chofyan. 2013. Pengelolaan Hutan Dalam Mengatasi Alih Fungsi Hutan di Wilayah Kabupaten Subang. Jurnal Perencanaan Wilayah dan Kota, 13 (2),1-11.

Latuconsina, Z. M. Y., Rustiadi, E., \& Sahara. (2017). An Analysis of the Level of Development in Malang Regency Based on a Typology of Development Regions. Journal of Regional and City Planning. 29 (1), 1-17.

Mishra, S. P., Sarkar, U., Taraphder, S., Datta, S., Swain, D. P., Saikhom, R., \&Laishram, M. (2017). Multivariate Statistical Data Analysis-Principal Component Analysis (PCA). Inernational Journal of Livestock Research, 7 (5), 60-78.

Monika, A. K. (2014). Analisis Perubahan Struktur Ekonomi Jawa Barat dengan Metode Biproporsional pada Tabel Input-Output. Jurnal Statistika \& Komputasi Statistik, 6 (1), 15-38.

Nazara, S. (2005). Analisis Input-Output. Lembaga Penerbit Fakultas Ekonomi Universitas Indonesia.

Neethu, C. V. \& Surendran, M. (2013). Review of Spatial Clustering Methods. International Journal of Information Technology Infrastructure, 2 (3), 15-24.

Nishom, M. (2019). Perbandingan Akurasi Euclidean Distance, Minkowski Distance, dan Manhattan Distance pada Algoritma KMeans Clustering berbasis Chi-Square. Jurnal Informatika: Jurnal Pengembangan IT (JPIT), 4 (1), 20-24. 
Putra, W. (2013). Model Perhitungan Besaran PDRB Hijau Sektor Kehutanan di Kalimantan Barat melalui Pendekatan Jasa Lingkungan. Jurnal EKSOS, 9 (1), 49-68.

Reza, M. S., \& Ruhi, S. (2015). Study of Multivariate Data Clustering Based on K-Means and Independent Component Analysis. Amerincan Journal of Theoretical and Apllied Sciences, 4 (5): 317-321.

Riqqi, A., Hendaryanto, Safitri, S., Mashita, N., Sulistyawati, E., Norvyani, D. A., Afriyanie, D. (2018). Pemetaan Jasa Ekosistem. Prosiding Seminar Nasional Geomatika 2018: Penggunaan dan Pengembangan Produk Informasi Geospasial Mendukung Daya Saing Nasional. Bogor.

Robhati, H. \& Kusumawardani, D. (2016). Estimasi Biaya Ekonomi Deforestasi di Indonesia tahun 2011-2013. Jurnal Ilmu Ekonomi Terapan, 1 (2), 34-50.

Roy, M. A. C., Rusdiana, O., \& Ichwandi, I. (2017). Dinamika Perubahan dan Kebijakan Pemanfaatan Ruang di Kabupaten Bogor, Provinsi Jawa Barat. Journal of Environmen Engineering \& Waste Management, 2 (2), 60-68.

Rustiadi, E. \& Kobayashi, S. (2000). Contiguous Spatial Classification: A new Approach on quantitative zoning method. Journal of Geography Education, 43, 122-136.

Sudrajat, A. (2016). Metode Principal Component Analysis untuk Mengatasi Multikolinearitas pada Regresi Linier Berganda (Studi Kasus Faktor yang Mempengaruhi Indek Pembangunan Manusia di Jawa Timur). Jurnal Penelitian Kesehatan, 14 (4), 201-208.

Suryanto. (2009). Mampukah PDB Hijau Mengakomodasi Degradasi Lingkungan dan Kesejahteraan Masyarakat? Jurnal Ekonomi dan Studi Pembangunan, 10 (1), 99-109.
Tajunisha \& Saravanan. (2011). An efficient method to improve the clustering performance for high dimensional data by Principal Component Analysis and modified K-means. International Journal of Database Management Systems (IJDMS), 3 (1), 196-205.

Wahyunto \& Dariah, A. (2014). Degradasi Lahan di Indonesia: Kondisi Existing, Karakteristik, dan Penyeragaman Definisi Mendukung Gerakan Menuju Satu Peta. Jurnal Sumberdaya Lahan, 8 (2), 81-93.

Widianingsih, Suryantini, A., \& Irham. (2015). Kontribusi Sektor Pertanian pada Pertumbuhan Ekonomi di Provinsi Jawa Barat. Agro Ekonomi, 26 (2), 206-218.

Wulandari, S. (2019). Pola Spasial Inkonsistensi Pemanfaatan Ruang dengan Keterkaitan Status Kepemilikan Penguasaan Lahannya di Sub DAS Ciliwung Hulu. Tesis. Institut Pertanian Bogor.

Yanti, T. S. (2015). Menaksir Matriks Teknologi Tabel Input Output Kota Bandung Menggunakan Metode RAS. Statistika, 15 (1), 7-15. 